\title{
Exploring Entrepreneurship \& Innovation's Practical Teaching Mode Based on Multidiscipline Coordination Learning among Economics and Management Specialties
}

\author{
Hao-Yuan $\mathrm{LI}^{1, \mathrm{a}}$ and Ping SONG ${ }^{2, b}$ \\ ${ }^{1}$ 410b, A7, Dalian University of Information, No.8 Software Park Road, Dalian, China \\ ${ }^{2} 410 a$, A7, Dalian University of Information, No.8 Software Park Road, Dalian, China \\ alihaoyuan@neusoft.edu.cn, ${ }^{b}$ songping@neusoft.edu.cn
}

Keywords: Entrepreneurship \& Innovation (E\&l), Multidiscipline Coordination, Practical Teaching.

\begin{abstract}
Under the guidance of “Mass Entrepreneurship and Innovation” policy in China, Chinese universities have been taking positive responses to the call. Dalian University of Information is trying to build a new entrepreneurship \& innovation education mode based on multidiscipline coordination learning among economics and management specialties. The new mode tries to solve the problems that specialty education is difficult to integrate with entrepreneurship \& innovation education, and a single major can hardly conduct entrepreneurship \& innovation education.
\end{abstract}

\section{Introduction}

In recent years, "Mass Entrepreneurship and Innovation" has become an important national developing strategy in China ${ }^{1}$. Based on this background, many universities carried out active explorations on Entrepreneurship and Innovation (E\&I) education. Great progressed has been achieved, however, there are still some problems needing urgent attention.

\section{Existing Problems}

\section{Separation between E\&I Education and Professional Education}

Currently, both domestic and international E\&I curriculum system mainly consist of entrepreneurship spirit courses, entrepreneurship theory courses, entrepreneurship skills and quality courses ${ }^{2}$. However, these different level courses are mainly general E\&I courses which are separate with professional education. Without professional education, E\&I education will lack of foundation, on the other hand, without E\&I education, specialty education will lost its direction and objectives ${ }^{2}$.

\section{Dilemma of Conducting E\&I Education by Single Specialty}

Entrepreneurship is a multidisciplinary business process, which needs to implement both professional business process and effective management system ${ }^{3}$, such as marketing activities, logistics process, e-business, human resource management, financial management and project management. For a single major, it can hardly build full-scale business and management knowledge architecture by itself, which means that students cannot experience whole E\&I processes and build a comprehensive understanding about E\&I and relative skills.

Therefore, how to integrate E\&I education with professional education, set proper teaching objectives and teaching methods, design proper teaching content is a subject worth researching and exploring in order to achieve optimum E\&I practice.

\section{Solutions}

Since 2015, Dalian University of Information created a new mode of E\&I education among economics and management specialties. A course named Collaborative Entrepreneurship and 
Innovation Practice (CEIP) has been taken as a pilot program in seven specialties including e-business, logistics management, marketing, human resource management, financial management, project management and information management. CEIP is a short term business practice course which takes four weeks and it will help students from participant with different specialties background, experience and practice real entrepreneurship and innovation processes.

\section{Teaching and learning Organization}

In CEIP course, students and teachers from different seven majors are mixed together into a class and build a multidiscipline specialties teaching organization. Each specialty needs to build its own practical teaching content system, and also one specialty's teaching content must be embedded as a part into the whole business project. In this organization, a student must be grouped with other six majors' students to achieve their business goal by cooperating effectively and efficiently. Figure 1 illustrates the structure of the organization.

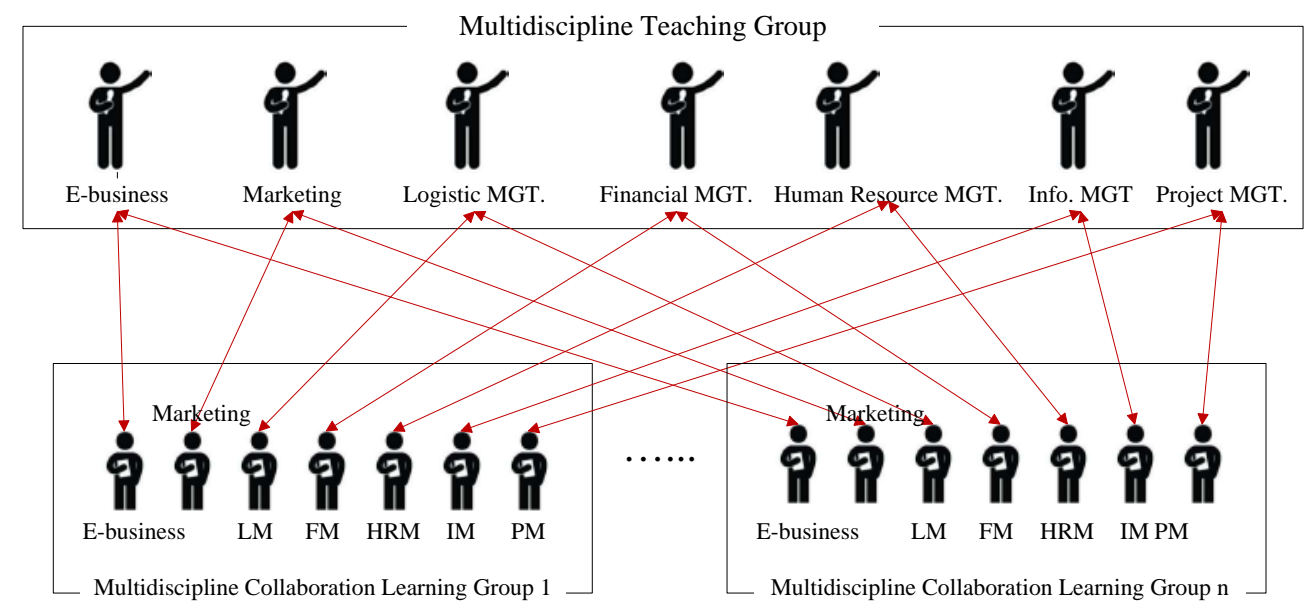

Figure1. Teaching and learning Organization of CEIP Course

As shown in figure 1, each student group must be composed of students from different majors. Some student groups might not need a specific major due to their business requirement. There are also seven teachers from the relative seven majors guiding and supporting student groups business from their own major aspects. For example, financial management teacher teaches and guides all financial students from different groups. By this kind of teaching organization, both collaborated teaching and multidiscipline business operation can be carried out smoothly. And the mixed teaching organization is much easier to create a real business operation environment which can conduct e-business, marketing, logistics process, financial management, human resource management, information management and project management through one business project in one course.

\section{Course Content}

\section{Practical and Real Project Approach}

CEIP course is conducted based on real business projects. Students who have business ideas, experiences or recourses can propose a plan first, and after being approved by course teacher, these ideas will be put into practice during the course period, and these students become leaders of their own teams. A certain amount of initial funds from course will be sponsored to each team, after four week's project operation, profit or loss is made by each student group, their financial performance will be taken into account in their course assessment.

In order to guarantee students projects can be implemented successfully, their projects must meet the following conditions. All student projects should include online and offline business. Online business meets the teaching and learning demand of E-business and marketing majors, while offline business meets the demand of logistics management majors. Seven majors mixture creates complex 
team management demand for student from human resource management. Financial management student should perform their duties on financial management in the team. In order to make sure every team goals can be achieved with limited initial fund and in fixed course period, student from project management will use their knowledge and skills to conduct time management, risk management. Since all projects could take advantage of information system like ERP to manage logistics, HR and network diagram. Table 1 shows the course CEIP course contents including learning outcomes of seven majors.

Table 1. CEIP Course Contents

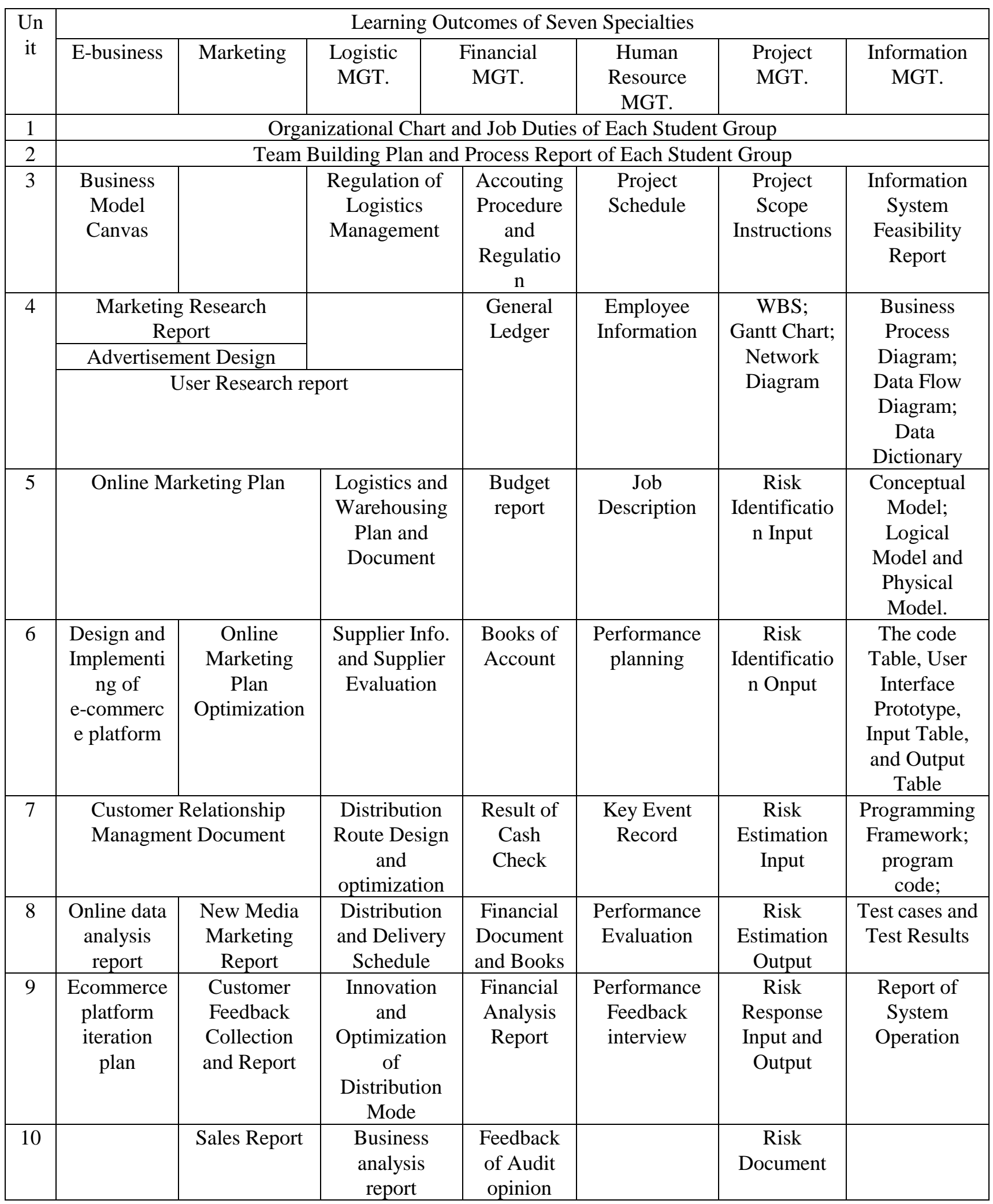




\section{Integration between E\&I and Specialty Education}

During the course, expect for operating a real business project and making profit as much as possible, student groups are encouraged to innovate from many aspects. For example, they can create a new business model for a traditional business by taking advantage of e-business, or they can pursue product or service innovation based on customer requirement study and marketing analysis, also they can create new way of getting profit. In order to do that, students have to put specialized knowledge they have learned before into practice. At the same time, if what they have mastered cannot meet the demand of business operation and management, they will learn new knowledge and skills by themselves with the guidance of course teachers. The principle of "learn to practice" will be carried out during the whole process of project. The innovation ideas, process and results will be taken into account in final performance evaluation. Figure 2 show the integration mode of E\&I education and specialty education ${ }^{4}$.

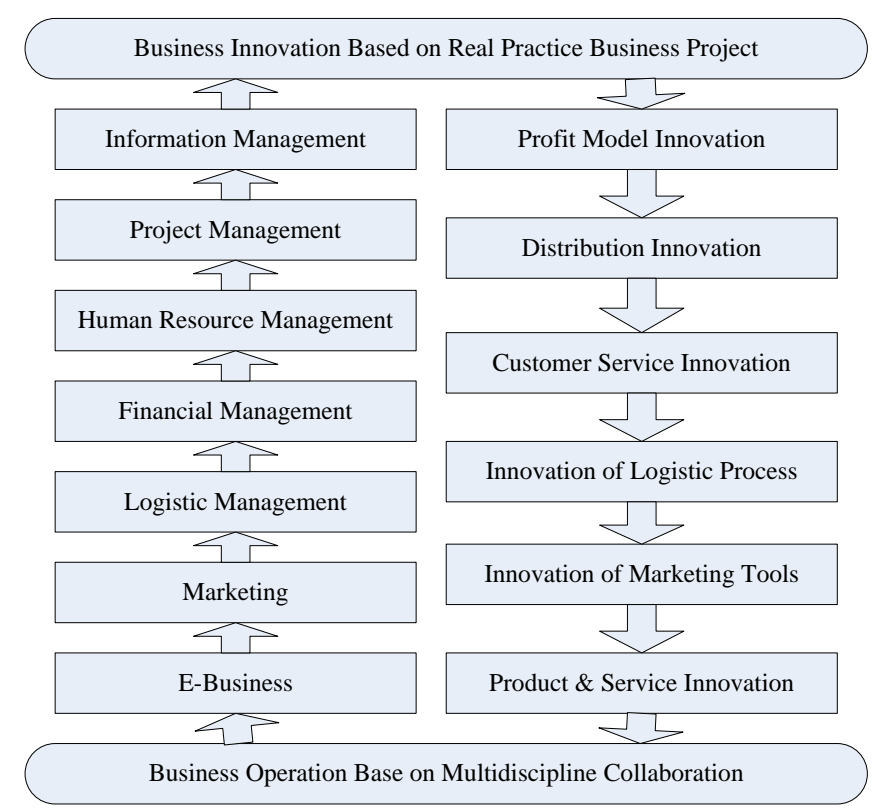

Figure 2. Integration Mode between E\&I and Specialty Education

\section{Teaching Methods}

\section{Experiencing Teaching"}

In the process of project operating, each student takes a role of a specific job position, and experience real work atmosphere. Since each student project is a real and need make profit as much as possible, student will perceive how his/her work affect the whole project positively or negatively. They will fully experience business operation and management of small business ${ }^{5}$.

\section{Problem Based learning}

During the project operation, student will face all kinds of problems and occasions that a small business might encounter. In CEIP course, instead of being taught knowledge and skills, student groups has to solve the problem on their own. Course teachers or other business experts, as a professional consultant; provide suggestions and methods instead of solutions. Therefore, student will promote their independent mind and improve their ability to use knowledge ${ }^{6}$.

\section{Real Case Teaching}

In CEIP course, teachers summarize many common experiences and lessons from student's own projects. Students can learn experiences directly in these real cases from a better perspective than books ${ }^{7}$. 


\section{Performance Evaluation}

In order to evaluate student's performance more objectively and comprehensively, CEIP course measure each student from three aspects, E\&I spirit, professional knowledge and E\&I practice. Different assessment methods have been chosen for relative assessment indicators ${ }^{8}$. Teachers, student leaders, human resource management students, financial management students participate in the performance evaluation process as examiners, which enhance the objectivity of the assessment. Table 2 shows the assessment system of CEIP course.

Table 2. Assessment of CEIP Course

\begin{tabular}{|c|c|c|c|c|}
\hline $\begin{array}{l}\text { Assessment } \\
\text { Content }\end{array}$ & $\begin{array}{l}\text { Assessment } \\
\text { Indicator }\end{array}$ & $\begin{array}{l}\text { Assessment } \\
\text { Method }\end{array}$ & Examiners & Credit \\
\hline \multirow{4}{*}{ E\&I spirit } & $\begin{array}{l}\text { Entrepreneurial } \\
\text { Potential }\end{array}$ & $\begin{array}{c}\text { Online Test of } \\
\text { Entrepreneurial } \\
\text { Potential }\end{array}$ & HR Student & 5 \\
\hline & \multirow{2}{*}{$\begin{array}{l}\text { Working } \\
\text { Attitude }\end{array}$} & $\begin{array}{c}\text { Attendance, overtime, } \\
\text { and dedication }\end{array}$ & $\begin{array}{c}\text { CEO, HR } \\
\text { Student }\end{array}$ & 5 \\
\hline & & $\begin{array}{c}\text { Star Member } \\
\text { Evaluation }\end{array}$ & CEO & 5 \\
\hline & Innovation & $\begin{array}{c}\text { Team Members } \\
\text { Presentation } \\
\end{array}$ & $\begin{array}{c}\text { Professional } \\
\text { Teacher } \\
\end{array}$ & 5 \\
\hline $\begin{array}{l}\text { Professional } \\
\text { knowledge }\end{array}$ & $\begin{array}{l}\text { Professional } \\
\text { Ability }\end{array}$ & Assignment & $\begin{array}{l}\text { Professional } \\
\text { Teacher }\end{array}$ & 20 \\
\hline \multirow{5}{*}{ E\&I Practice } & $\begin{array}{c}\text { Innovation } \\
\text { Performance }\end{array}$ & Innovation Dedication & $\begin{array}{c}\text { Professional } \\
\text { Teacher } \\
\end{array}$ & 10 \\
\hline & Team Building & $\begin{array}{l}\text { Team Building } \\
\text { Evaluation }\end{array}$ & HR Student & 10 \\
\hline & Collaboration & Team Presentation & $\begin{array}{c}\text { Professional } \\
\text { Teacher } \\
\end{array}$ & 10 \\
\hline & Profitability & Finance Performance & $\begin{array}{c}\text { Financial } \\
\text { Management } \\
\text { Student } \\
\end{array}$ & 20 \\
\hline & $\begin{array}{c}\text { Problem-solving } \\
\text { Ability }\end{array}$ & $\begin{array}{l}\text { Team Members } \\
\text { Presentation }\end{array}$ & $\begin{array}{l}\text { Professional } \\
\text { Teacher }\end{array}$ & 10 \\
\hline
\end{tabular}

\section{Summary}

After 3 rounds of CEIP course, Dalian University of Information gradually accumulated substantial teaching experiences through multidiscipline coordination learning among economics and management specialties, including how to choose student projects, how to manage teaching and learning processes and organizations, how to design teaching contents of seven different majors and make them an integrated system. Our exploration has achieved great results; we have established an integral and integrated teaching management process, cultivated a lot of student entrepreneurship pioneers, and cultivated a group of entrepreneurship teachers. Through continuous exploration, the problems of separation between E\&I education and specialty education, dilemma of conducting E\&I education by single specialty are finally solved. Moreover, multidiscipline coordination learning mode improves the quality of teaching in an all-round way, and meets the needs of the state and society in the new period for innovative and entrepreneurial talents. 


\section{Acknowledgement}

This research was financially supported by the Liaoning Province Undergraduate Education Reform Foundation.

\section{References}

[1] Information on http://www.mof.gov.cn/

[2] Dan Cheng, Jian Zhao, Zengrong Zhan, Discussion on the mode of collaborative innovation and entrepreneurship education in foreign universities and its enlightenment to China, Science and Technology Entrepreneurship. 12 (2014) 42.

[3] Jian Zhou, Research on the training mode of innovative and entrepreneurial talents in Colleges and Universities, The road to talent. 15 (2016) 22-24.

[4] Junsheng Wang, Interaction and mutual construction of collaborative innovation and entrepreneurial universities, Journal of Zhengzhou University (Philosophy and Social Science Edition). 46(2) (2013) 78-79.

[5] Xiaobing Zeng, The exploration and practice of simulated Experiential Teaching -- Innovation of the training mode of economic management talents with ERP experimental teaching as a breakthrough, Laboratory Research and Exploration. 25 (3) (2006) 273-275.

[6] Jie Wang, Canhua Jiang, Cultivation of undergraduate self-learning ability and general quality under the environment of entrepreneurship and innovation, Higher Education Exploration. 11 (2016) 117-119.

[7] Changping Chang, Chun Yan, The construction of the mimicry environment for the case teaching of innovation and Entrepreneurship of College Students, Higher Education Forum.11 (2017)44-46.

[8] Jianqiu Han, Meiyu Zhou, Chaohua Wang, Research on the construction of course assessment system based on the cultivation of innovative and entrepreneurial ability of College Students, Journal of Higher Education.07 (2016) 29-30 